\title{
EU NÃO ALCANCEI ESTE TEMPO: \\ FOTOGRAFIA E ANCESTRALIDADE NO ALTO DA BELA VISTA, \\ ITAPARICA (BA)
}

\author{
Andréa Silva D'Amato ${ }^{1}$ \\ "A morte é como o umbigo do mundo: \\ o quanto nela existe é a sua cicatriz, \\ a lembrança de uma anterior existência."
}

(Couto, 2003: 15)

\section{A imagem que não se fixou, morte e vida no pensamento iorubá}

Parece que as palavras querem substituir as imagens que não estou fazendo nessa viagem ${ }^{2}$. Neste momento acho que vivenciei uma das cenas mais impressionantes - para mim - dentro do candomblé (fora todo o meu processo de iniciação) ${ }^{3}$. Na verdade não vimos nada, apenas ouvimos, mas a energia era, de fato, ancestral. Fomos convidados a deixar o barracão protegidos pelo mariô (folha de dendezeiro desfiada) amarrado em nossos pulsos. Lá fora, no quintal externo, o terreno baldio sob a noite escura parecia imenso. Uma casinha com o reboco rústico e uma tinta branca já bem gasta era iluminada pela lua. Bem ao lado, um enorme pé de mangueira parecia nos observar. Palavras em iorubá proferidas pelos ojés (iniciados no culto a babá-egún) e o barulho dos ixans batendo no chão (varas rituais usadas pelos ojés para evocar e controlar os egúngún ${ }^{4}$ ) eram emitidos de dentro da pequena casa. De repente, um som diferente começou a ser entoado, uma espécie de gemido que aos poucos foi ganhando força até se transformar em um lamento alto. Era a morte se tornando vida, a ancestralidade que estava ali renascendo no aiyê (terra, mundo que habitamos). A

\footnotetext{
1 Universidade Federal de São Paulo, Brasil Email: andrea@andreadamato.com.br ORCID id: https://orcid.org/0000-0003-2326-2620

${ }^{2}$ Viagem de campo realizada nos meses de janeiro e fevereiro de 2019.

${ }^{3}$ Fui iniciada no Ilê Axé Opô Aganjú, em Lauro de Freitas, na Bahia, em janeiro de 2011.

4 No iorubá não existe o plural designado com a letra "s", por isso, a pedido de um interlocutor, babáegún, egúngún e egún serão utilizados no singular, mesmo quando se tratar de mais de um. Ainda que a grafia aportuguesada do ioruba tenha sido adotada para facilitar a leitura.
} 
iniciação parece ser um renascimento em vida, e o axexê (ritual fúnebre) um renascimento ancestral. Egúngún (ancestral) estava sendo invocado ali no lessé-egún (casa do segredo onde apenas os iniciados do culto tem acesso) bem na minha frente e eu não estava vendo nada, mas ouvindo tudo. Até que um babá (pai/ancestral) respondeu já em festa com sua voz forte, rouca e gutural. Fiquei imaginando sua chegada com a roupa inflando... falou, cantou e muito provavelmente dançou também, todos do lado de fora pareciam ansiosos para que a porta se abrisse. Depois de um tempo isso aconteceu, mas só os ojés saíram. Percebi uma certa decepção entre os presentes, ouvi alguns comentários quando estávamos retornando para o barracão. Eu, por minha vez, mesmo sem ver, voltei um tanto encantada, sabia que eu tinha acabado de participar de uma força que está para além de minha compreensão, escutar e sentir aquilo tudo, mesmo sem ver, me deixou com a sensação de que não precisava dos olhos para ver, o que eu estava observando era invisível, a força da ancestralidade sendo transmitida para aquele terreiro, para aquele chão a nossa frente, ao pé da mangueira, sob a luz do luar, alumiando todos nós.

A cena descrita acima aconteceu em um terreiro de culto a orixá em Itaparica durante o axexê de 12 anos da mãe de santo da casa. Algumas casas tradicionais de candomblé costumam assentar os ancestrais de lideranças do terreiro, esses assentamentos são mantidos em um espaço sagrado chamado lessé-egún, distante do local onde ficam os assentamentos dos orixás, o lessé-orixá. Os assentamentos desses ancestrais ilustres não devem ser confundidos com os babá-egún, que são ritualmente preparados para serem evocados em rituais e terreiros específicos deste culto. Babáegún ou egúngún é a energia primeva e potencializada dos ancestrais que foram importantes dentro da comunidade, enquanto egún é um termo mais abrangente que designa qualquer pessoa falecida em sua forma primitiva, já os ancestrais ilustres são homenageados durante a cerimônia do padê antes das festas públicas nos terreiros de culto aos orixás.

"É a voz dos mortos que se faz ouvir na ilha de Itaparica" (Bastide, 1971: 360), atualmente são mais de 12 terreiros de culto a babá-egún estabelecidos neste pedaço de terra cercado de água por todos os lados, fora as inúmeras casas de orixás que também mantém o lessé-egún. Pode parecer um tanto estranho iniciar um texto que pretende abordar a potência das fotografias descrevendo uma imagem que não se fixou. Nossos sentidos tateiam, exploram, rastreiam e produzem percepções em um campo de 
implicações cruzadas. A reflexão etnográfica a que se propõe este artigo é um exercício de pensamento a fim de diluir oposições binárias entre morte e vida, visível e invisível, presença e ausência, profano e sagrado, dentre outros; e (re)pensar a linguagem em uma rede de conexões e agenciamentos composta por experiências tangenciadas por humanos e não-humanos, onde o mundo dos mortos e o mundo dos vivos se conectam e se inter-relacionam.

A experiência tem lugar no pequeno povoado do Alto da Bela Vista, localizado na praia de Ponta de Areia, município de Itaparica, no estado da Bahia. O tempo de viagem até a capital, Salvador, dura cerca de duas horas. São dois os acessos, o trajeto inclui uma caminhada a pé, um transporte coletivo (na maioria das vezes informal) e a travessia da baía de Todos-os-Santos, que pode ser feita de Ferry (via Bom Despacho, Itaparica) ou por lanchas (via Mar Grande, Vera Cruz). Particularmente, envolve os moradores do entorno do terreiro Omo Ilê Agboulá e seu culto aos ancestrais, conhecidos como babá-egún. $\mathrm{O}$ intuito da pesquisa é revisitar arquivos e fotografias sobre a comunidade e seus rituais, com a finalidade de provocar agenciamentos e reflexões, e assim compreender as possibilidades de agentividade das imagens. A ideia é compartilhar aspectos de minha interlocução com anfitriões e frequentadores do terreiro sobre memórias, histórias e presenças acionadas pelas fotografias.

O Omo Ilê Agboulá é descendente direto de uma linhagem de antigos terreiros de culto aos egúngún estabelecidos na ilha de Itaparica há cerca de duzentos anos ${ }^{5}$. Fundado em 1934 pelos irmãos Pedro, Olegário e Eduardo Daniel de Paula, o terreiro foi tombado pelo Iphan como patrimônio cultural em 25 de novembro de 2015. Durante os cultos, o ancestre volta para sua comunidade (egbé) para dar conselhos e orientações, seu retorno sempre é celebrado com festa. Diferente do culto aos orixás, no culto a babá-egún não existe o transe, os babá não são recebidos pela possessão, eles se materializam. Para aparecer, dançar e se comunicar, o egúngún precisa do axó (roupa), vestimenta colorida, adornada com búzios e espelhos, é uma massa de ar que preenche o traje e transforma-se no corpo do ancestral. Isto é, a roupa sagrada canta, dança, fala e interage sem que exista um corpo humano debaixo do pano, quem habita a roupa é o próprio egúngún, o espírito ancestral. $\mathrm{O}$ axó é especialmente preparado, considerado

\footnotetext{
${ }^{5}$ O primeiro terreiro foi o de Vera Cruz, fundado por volta de 1820 na Ilha de Itaparica, depois vieram o terreiro de Mocambo, em 1830, o terreiro da Encarnação, em 1840, o terreiro de Tuntun, em 1850. Este último continua em atividade ainda hoje.
} 
sagrado e, por isso, propagador de axé, força propulsora que movimenta a vida. É composto por três partes delicadamente bordadas. O abalá, uma armação quadrada ou redonda, como se fosse um chapéu, que cobre totalmente a extremidade superior, e da qual caem várias tiras de panos coloridos. O kafô, uma túnica de mangas que acabam em luvas e pernas que acabam em sapatos, do qual também caem muitas tiras de pano da altura do tórax. E o banté, uma larga faixa de pano presa ao kafô. Os babá costumam sacudir o banté na direção dos seus descendentes para que o seu axé seja transmitido. No artigo "Conhecimento e memória no culto de Egún: a confecção da casa-corpo da morte" a pesquisadora Stela Guedes Caputo (2011: 677) sugere que os ensinamentos adquiridos nos terreiros de egúngún nos desafiam a não lutar contra a morte, mas sim a lutar contra o esquecimento.

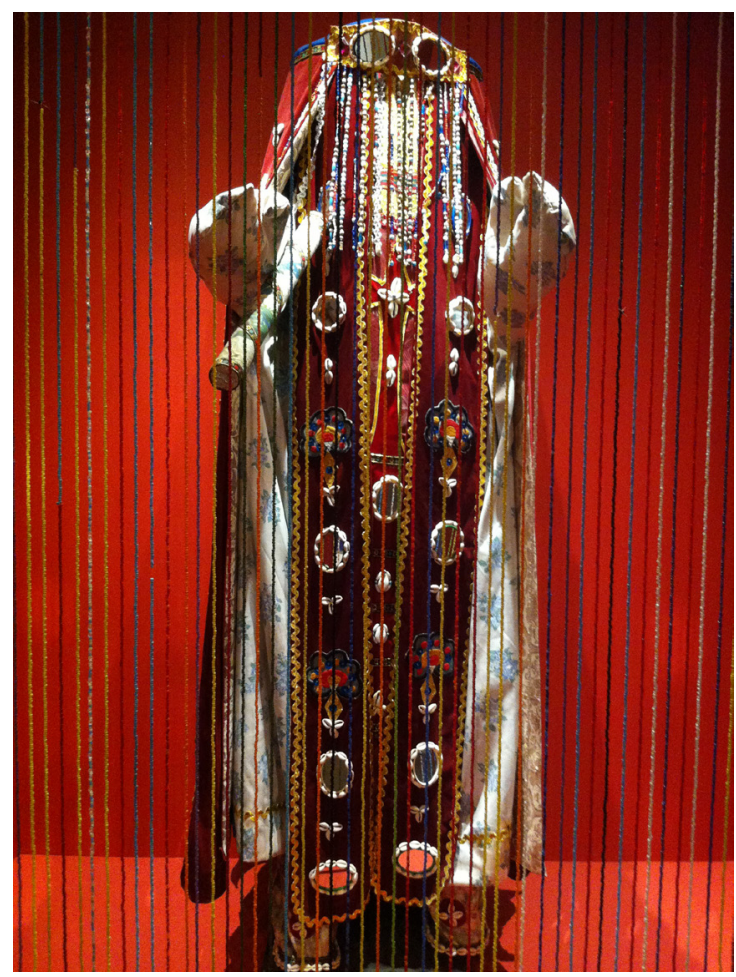

Figura 4: Axó, em exposição no Museu Afro Brasil, em São Paulo. Foto: Andréa D’Amato.

Nos terreiros de egúngún são dois títulos para as lideranças principais. O alagbá, que é o líder de uma determinada casa e o alapini, sacerdote supremo, responsável por todas as casas e líder dos alagbá. Atualmente, o posto de alapini está vago desde a morte de Mestre Didi (1917-2013). Essas lideranças são auxiliadas por outros diversos cargos, sempre masculinos, entre eles: atokun (guia de egún), ojé agbá (ojé mais velho), ojé (iniciado com ritos completos), amuixan (iniciado com ritos incompletos), alagbê 
(tocador de atabaque). As mulheres não podem ser memoradas na forma de egúngún. Toda a hierarquia dentro do terreiro é masculina. Apenas os homens podem ser iniciados nos segredos do culto, apesar de existirem cargos femininos para outras funções como: iyalodê (responde pelo grupo feminino), iyá egbé (cabeça de todas as mulheres), iyá mondê (comanda as atós e fala com os Babá-Egún), iyá erelu (cabeça das cantadoras), erelu (cantadora), ató (adoradora de Egún) e diversos outros. A ancestralidade feminina, por sua vez, é cultuada de forma coletiva por meio das poderosas e respeitadas İyá-mi ${ }^{6}$ nas sociedades geledés, composta exclusivamente por mulheres.

De acordo com Balbino Daniel de Paula, alagbá no Ilê Agboulá, “a morte não é o fim, mas uma etapa para o recomeço que é eterno e se renova unindo passado e presente como prática religiosa" ${ }^{7}$. A realidade entendida como dimensões de tempo convergidas no espaço de um corpo-roupa se atualiza cotidianamente e traz a concepção de existência - que na cultura iorubá transcorre simultaneamente em dois planos. O aiyê compreende o universo em que estamos e a vida de todos os seres naturais que o habitam, sobretudo, os ara-aiyê, os seres humanos. E o orun, uma dimensão paralela formada por nove espaços sagrados habitados pelos ara-orun, divindades do culto nagô ${ }^{8}$. Juana Elbein dos Santos (2012: 55-56) nos explica que o orun é um universo que coexiste com todos os conteúdos do mundo real. Cada indivíduo, cada árvore, cada animal, possui um duplo abstrato no orun. Ou, ao contrário, tudo o que existe no orun tem suas representações materiais no aiyê. $O$ mito fundante ${ }^{9}$ da cosmologia das religiões de matriz africana demonstra que a pedido de Olorun o universo foi criado por Odùdùwa, poder feminino, responsável pelo aiyê e Obatalá, poder masculino, responsável pelo orun.

\footnotetext{
${ }^{6}$ Iyá-Mi é a síntese do poder feminino, claramente manifestado na possibilidade de gerar filhos e, numa noção mais ampla, de povoar o mundo. O seu grande poder deve-se ao fato de guardar o segredo da criação. As Iyá-mi, juntamente com exú e os ancestrais, são evocadas nos ritos de Ipadé, um complexo ritual que, entre outras coisas, ratifica a grande realidade do poder feminino na hierarquia do candomblé, denotando que as grandes mães que detém os segredos do culto, pois um dia, quando deixarem a vida, integrarão o corpo das Iyá-mi, que são, na verdade, as mulheres ancestrais.

${ }^{7}$ Disponível em: http://atarde.uol.com.br/muito/noticias/1635733-balbino-o-culto-a-egungun-preserva-olaco-coletivo. Acesso em: 31 de janeiro de 2020.

${ }^{8}$ Os iorubás ou nagôs constituem um dos maiores grupos étnicos-linguísticos da África Ocidental, originários da antiga república do Daomé (atual Nigéria e Benin). Nagôs era a designação dada aos negros escravizados que falavam o iorubá.

${ }^{9}$ Existem diversas pesquisas com diferentes enfoques e versões sobre a criação do mundo no conceito ioruba, entre estas: Juana Elbein dos Santos (2012), José Beniste (2010) e Adilson de Òsàlá (2006).
} 
Odùdùwa criou a terra e Obatalá criou todas as criaturas do orun, cujos duplos serão encarnados na terra. Entre os aspectos que proporcionam a vida no aiyê podemos $\operatorname{citar}^{10}$ :

a) o Ori, a cabeça que tudo orienta, o ori-aiyê está ligado ao ori-orun

b) o Ara, corpo físico

c) o Bará, princípio dinâmico individualizado. Exú é o princípio dinâmico e de expansão, sem ele todos os elementos do sistema e o seu devir ficariam imobilizados, a vida não existiria. Bará é o exú individual, cada pessoa vivente no aiyê possui o seu próprio princípio dinâmico.

d) o Odu, caminho ou destino

e) o Orixá, energia originária presente na criação do aiyê, a natureza viva.

f) o Axé, energia vital que tudo movimenta

g) o Emi, elemento original soprado por Olorun, sopro sagrado, hálito, saliva (palavra soprada), respiração

h) o Egún, matéria ancestral, nossa parte sociável e individualizada que preserva a existência coletiva

Retomando a noção defendida por Marcio Goldman (1985), a pessoa no candomblé é formada ao longo de sua feitura de acordo com as entidades que vão sendo incorporadas à sua cabeça. O orixá nasce junto com um filho de santo e a feitura é um processo que não tem fim, a cada obrigação acrescenta-se mais algum componente à pessoa. Segundo Clara Flaksman (2016:15), a questão fundamental trazida por Goldman é que a feitura, esse processo que se renova ao longo da vida mediante determinadas obrigações, traria estabilidade para a pessoa que, por princípio, é instável e sujeita a forças fora de seu controle. Mediante ao conceito de 'enredo', Flaksman (2016:13-14) pontua que a pessoa no candomblé é um conjunto de suas relações, ou melhor, um complexo de relações, que podem se dar de inúmeras maneiras e em planos diferentes. No livro Os nàgó e a morte, Juana Elbein dos Santos (2012: 253-254) relata que, para o povo iorubá, a morte/iku, elemento masculino, é uma mudança de existência, faz parte da dinâmica de um sistema, inclusive de uma dinâmica social. A autora afirma que o ser que completou com sucesso a totalidade de seu destino/odu está

\footnotetext{
10 Necessário esclarecer que as informações fornecidas são breves e sucintas, a explanação de cada um desses elementos deve e merece ser desdobrada, ver Juana Elbein dos Santos (2012).
} 
maduro para a morte. Assim, iku (a morte) é indispensável para a restituição, reacomodação da ordem social e manutenção do axé, tanto no aiyê como no orun.

A existência simultânea no aiyê e no orun formam um ciclo ininterrupto de vida. Uma vez cumprido o seu ciclo no aiyê, cada ser humano se desintegra para restituir-se às massas progenitoras e reforçar o axé das mesmas no orun. Cada um dos elementos que constitui a pessoa segue uma trajetória específica após o axexê, ritual fúnebre realizado para retirar os fundamentos colocados na cabeça do iniciado no momento de sua feitura. Quanto maior o axé de uma pessoa no aiyê e mais alta sua hierarquia na tradição dentro do terreiro, mais complexo será o axexê. Dessa forma o ori-aiyê junta-se novamente ao ori-orun. $\mathrm{O}$ ara (corpo), que fora modelado com uma porção de lama, deverá reintegrar-se a terra. Assim como o emi (sopro sagrado, respiração) desprende-se do corpo e retorna á massa de ar que lhe deu origem. E o egún transforma-se em ancestre e poderá, depois de receber os rituais pertinentes, ser evocado como babá-egún. Porém, os ritos se diferenciam naqueles que serão cultuados como egúngún após a morte.

Não há nenhuma confusão entre a realidade do aiyê - o morto - e seu símbolo, ou o seu duplo no orun, o egún. Porém, para poder ser evocado como babá-egún, o ancestre também passa por rituais e processos de "feitura" após o axexê, que se diferenciam daqueles realizados nos processos de "desfeitura" ${ }^{11}$ no axexê dos cultos aos orixás. Com um ano faz-se a primeira invocação e evocação convocando o morto, em uma cerimônia denominada aku, reservada aos membros do terreiro, cujo objetivo é romper definitivamente todos os laços de parentesco do falecido e estabelecer um outro, mais sagrado, preparando-o para seu futuro retorno. $\mathrm{Na}$ obrigação de três anos o ancestre (egún) torna-se aparaká, espécie de guardião do culto, porém, ainda em processo de formação, com presença frequente e garantida nas festas de Babá. Nessas ocasiões rondam todo o terreiro, por isso, aconselha-se adentrar o local com calma e em silêncio, sempre na companhia de um ojé. Os aparakás são mudos, não emitem nenhum tipo de som e ainda não possuem sua identidade revelada, portanto a sua forma/corpo é indefinida e sua roupa é apenas um pano, quadrado, reto na frente e atrás. E só após a obrigação de sete anos o ancestre poderá finalmente abrir a fala, ganhar o axó (roupa) e tornar-se um babá-egún, a partir disso estará apto para aparecer em público e se

\footnotetext{
$\overline{11}$ Termo utilizado por Flaksman (2016: 27).
} 
comunicar com seus descendentes. O egúngún, babá-egún ou simplesmente babá aparece inteiramente recoberto com seu axó colorido, o que permite aos espectadores perceberem formas humanas de diferentes alturas e corpos. Por ser uma materialização da própria morte, não é permitido a nenhum ser humano tocar em um egúngún. Para evitar que isto aconteça, os ojés os controlam por intermédio do ixan, varas rituais especialmente preparadas, e impedem que o axó encoste nos participantes. Os babá possuem uma voz rouca e gutural, com um tom bem grave, ou muito fina, com um tom demasiadamente agudo. A fala é em iorubá, normalmente traduzida por um ojé, embora muitos participantes compreendam o que os babá dizem e conversem normalmente com eles. Nessas ocasiões ocorre um diálogo entre os ancestrais e seus descendentes, as pessoas falam livremente de suas angústias e os egúngún, por sua vez, as orientam. Estabelece-se a dimensão de um mundo compartilhado por vivos e mortos.

O que acontece nas cerimônias aos babá-egún é uma atualização constante que redefine as experiências de morte e ancestralidade. Os terreiros são espaços de circulação onde importantes conhecimentos de relações de matriz africana são partilhados, "não se trata de um saber cristalizado imutável" (Braga, 1995: 41) , as culturas orais não são estáticas. Segundo Jérôme Souty, a memória das sociedades orais é uma memória assimilada e reinterpretada, ou seja, deixa o campo livre para a expressividade dos atores, fluida e movediça, a tradição oral é uma recriação permanente. "As culturas que se escoram na ideia de 'tradição' são aquelas que se fundamentam no uso de manuscritos e não as chamadas 'tradicionais', que têm na oralidade seu suporte privilegiado. É a escrita que inventa a 'tradição', dando-lhe essência e cristalizando-a." (Souty, 2011: 227). Tais aspectos podem ser apreciados, inclusive, no idioma iorubá, "os verbos costumam ser polissêmicos, com muitas semânticas e significados, não flexionam nas conjunções, por isso são sempre apresentados na forma infinitiva, assim, não sofrem modificações para apresentar o tempo presente, passado ou futuro, são utilizadas partículas para indicar a conjugação. (Jagun, 2017: 33). Além disso, “a princípio, os verbos de ação são sempre lidos no tempo passado; os verbos neutros, são lidos no tempo presente e passado; e os verbos sem indicação do tempo, devem sempre ser entendidos no passado" (Jagun, 2017: 32). Para simplificar, podemos dizer que as sociedades orais cultivam a arte dinâmica e viva da memória. Mas e quando esse passado foi fixado em fotografias? Quais as relações possíveis e (ini)magináveis? 


\section{A memória estava toda empoeirada na sacola}

Cheguei a casa de Dona Zeinha com algumas fotos de Pierre Verger nas mãos. Fui para conversar sobre as imagens e ouvir as histórias que poderiam me contar. Ao ver as fotografias, Leninha (filha de D. Zeinha) logo falou "nossa comunidade não tem memória". A prosa foi avançando despretensiosa e sem pressa. "Esse aqui é tio Izidoro. Vovó Julia aqui. Mainha é mainha, é ela sim”. Leninha, já emocionada, se levanta, vai até o outro cômodo e volta com uma pasta. Lá dentro muitas, mas muitas fotografias, e um outro tanto de lembranças que se desdobraram. Provoquei Leninha: " viu, quanta memória!". Ela rapidamente arrematou: pois é, a memória estava toda empoeirada na sacola”.

Ao sair da casa de D. Zeinha, as crianças já estavam a minha espera no portão. Como fazíamos todas as tardes deixei minha máquina e meu celular nas mãos da criançada e fomos fotografar. O conjunto etnográfico que compõe este estudo é formado por fotografias vernaculares de períodos distintos encontradas nos álbuns de família de meus anfitriões; imagens de Pierre Verger realizadas no período entre 1948 e 1950, e fotografias realizadas por Daniele, Emidia, Gustavo, Jaciara, Jonathan, Jamile, Layane e Lorrana nos meses de janeiro e fevereiro de 2019.
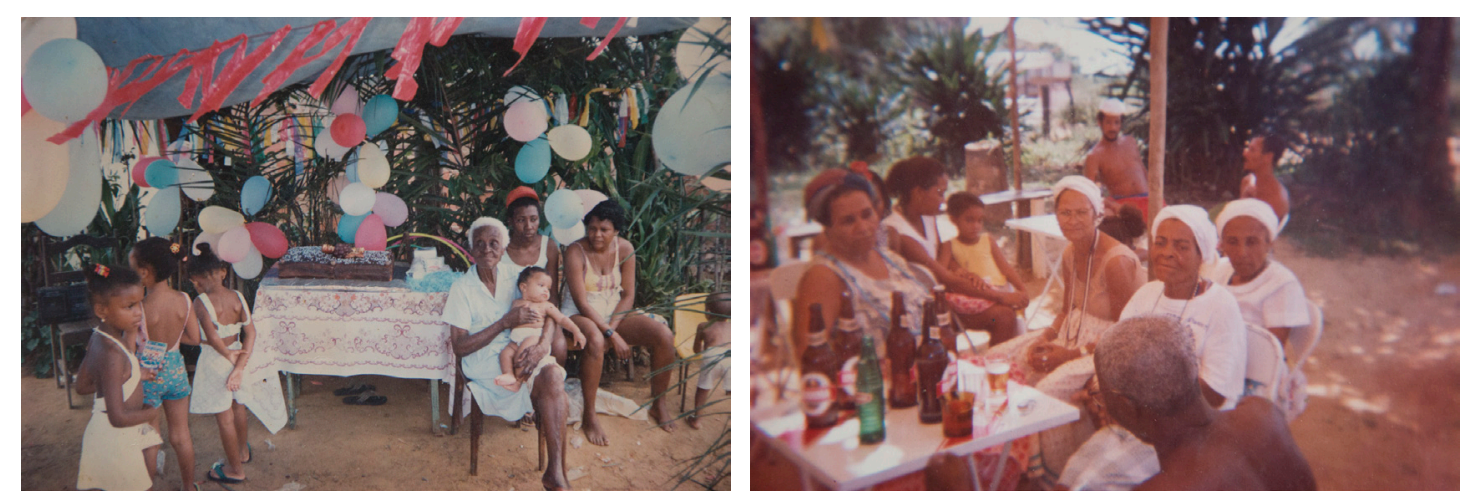

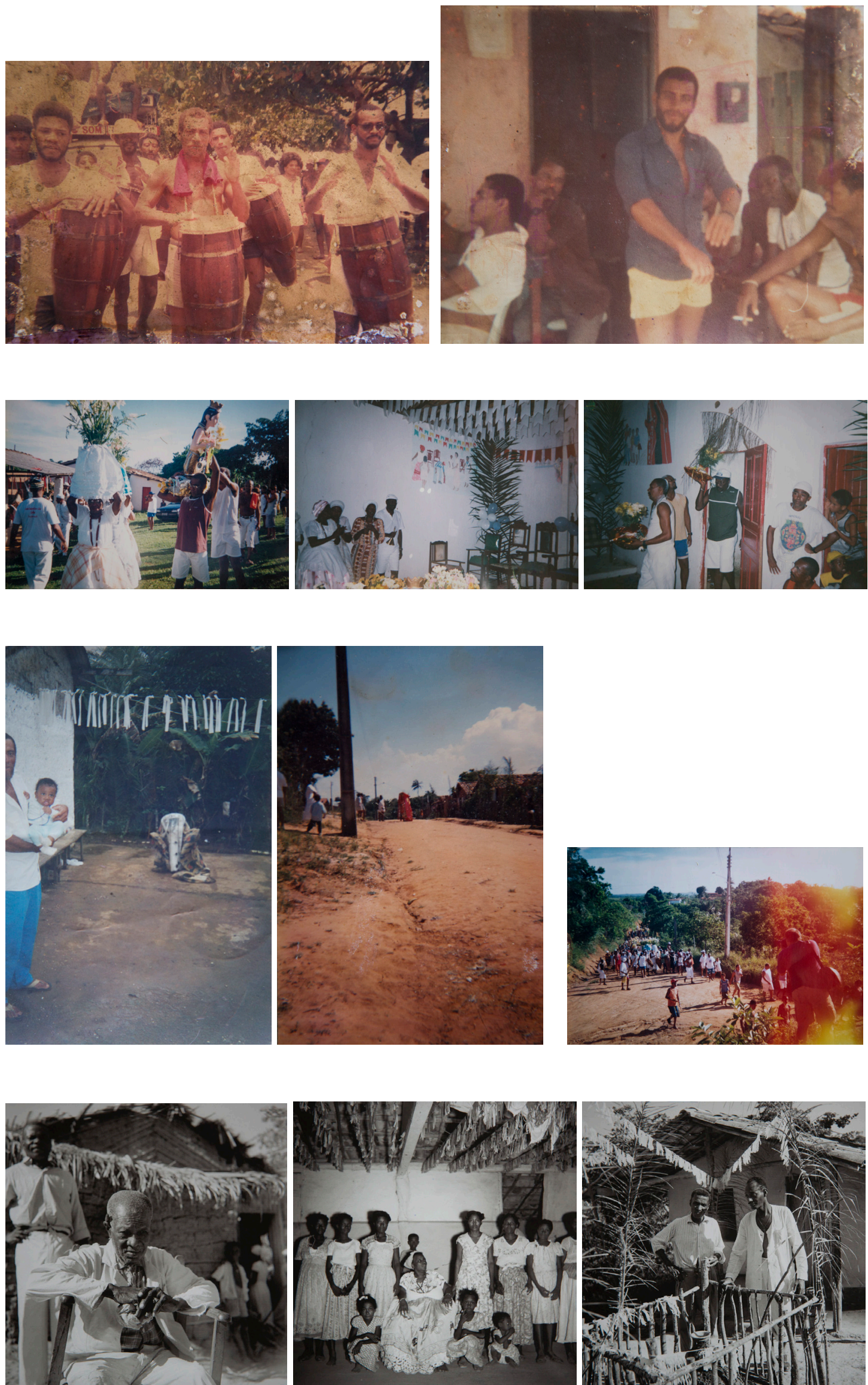

Iluminuras, Porto Alegre, v. 21, n. 53, p. 193-211, julho, 2020. 

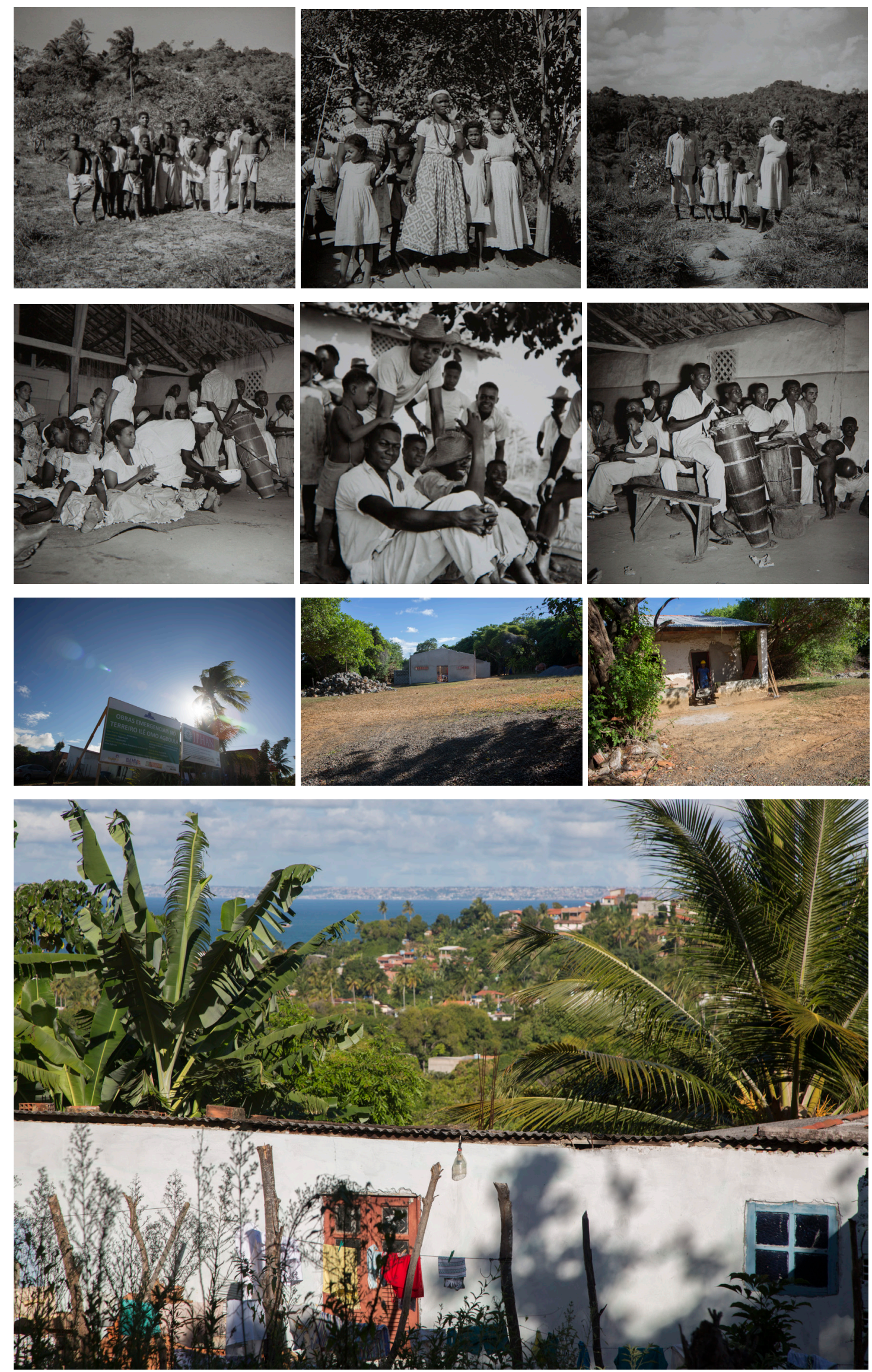

Iluminuras, Porto Alegre, v. 21, n. 53, p. 193-211, agosto, 2020. 

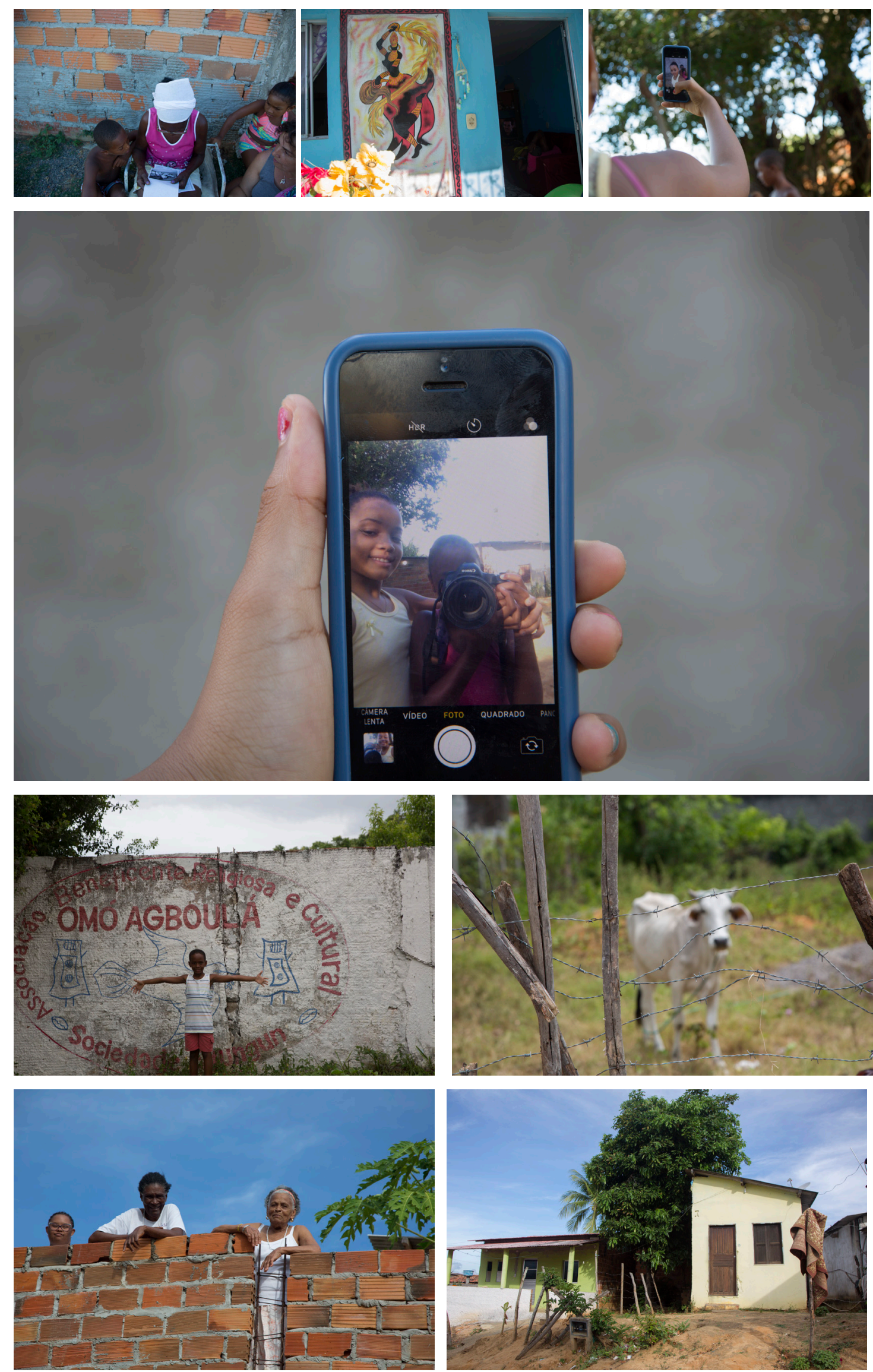

Iluminuras, Porto Alegre, v. 21, n. 53, p. 193-211, julho, 2020. 
"As pessoas, cada uma tem o seu olhar. Para falar de uma fotografia dessa requer muita observação", me disse Vovó Cici, ${ }^{12}$ quando lhe pedi que comentasse sobre as fotos de Pierre Verger. Vendo as imagens esquecidas na sacola, Dona Zeinha comentou: "Quando a gente olha as fotos parece que as pessoas estão com a gente de novo". Ao contemplar o conjunto de imagens (de Verger, familiares e das crianças) o alagbá Balbino Daniel de Paula disparou: "A gente se vê há 40 anos e a história se repetindo hoje com outros personagens. Tem coisa do tempo que a gente não pode entender, assim é a ancestralidade, ela está no passado, mas está aqui no presente. A história se repete." A ancestralidade reverenciada nas cerimônias a babá-egum desafia os limites da existência humana e da morte como instauração de um tempo passado. As rupturas não pertencem a este raciocínio que tem a morte como constraste ativo, como perspectiva outra, e como não oposição à vida. “A morte é coisa viva” (COUTO: 2003, pag. 86) e as temporalidades não são absolutas.

"Eu não alcancei este tempo". Escutei esta frase repetidas vezes. Uma maneira de me contarem que ainda não eram nascidos quando a foto foi realizada. A frase, geralmente proferida pelos mais novos, parece trazer à tona a astúcia das fotografias contra uma razão linear. A ação do verbo remete ao futuro mas o contexto nos direciona para o passado e tensiona o limiar entre as bordas do tempo. Nessa gramática encontramos uma temporalidade em movimento que atravessa e evidencia as relações. "Este é precisamente o movimento através do qual o candomblé busca conduzir seus adeptos - em direção ao futuro que volta ou reassume o passado" (RABELO: 2014, pag. 77). Operar na transversalidade e considerar realidades e tempos distintos movimenta esta lógica de pensamento no qual a morte se torna o principal elemento, inclusive, para se perceber a dinâmica da vida. Nessa intricada rede de conexões e ramificações encontramos um emaranhado de temporalidades promovendo novos sentidos e valores entre os que dele participam, os afetos oscilam, as relações se transformam e se atualizam. Passado e futuro parecem estar conjugados em um presente intenso.

\footnotetext{
${ }^{12}$ Nancy de Souza, egbomi (irmã mais velha) do ilê axé opó Aganju e griot (contadora de história e guardiã da palavra) na fundação Pierre Verger.
} 
Assim como as fotografias atestam a ausência do que elas fazem presente, os babá-egún necessitam da corporificação, por meio do axó, a casa-roupa sagrada, para adquirir uma forma e visibilidade provisórias. Nos dois casos, a ausência visível é transformada em uma nova forma de presença. Como em um ato ritual, as fotografias contêm seus mistérios, participam de agenciamentos, enredos, e este parece ser o grande desafio que as imagens colocam para a pesquisa etnográfica, grafias e ancestralidade são mediadoras nessas artes de evocar outros imanentes, que se fazem presentes por sua ausência, que se fazem visíveis ao coexistirem em outro tempo-espaço. A escrita deste texto e as imagens que o habitam também participam desse movimento, fazendo visíveis relações e aprendizados cuja condição de existência é serem outras em relação àquilo que evocam.

\section{As fotografias}

O conjunto etnográfico de imagens que participa deste artigo é formado por fotografias de tempos e contextos distintos. São dez fotografias do álbum familiar de D. Zeinha, "guardadas na sacola", reproduzidas em janeiro de 2019, durante visita a casa de uma de minhas anfitriãs no Alto da Bela Vista em janeiro de 2019. Nove fotografias de Pierre Verger, realizadas no período de 1948 a 1950 no Barro Vermelho, localidade onde na época estava instalado o Omo Ilê Agboulá. As fotografias foram gentilmente cedidas pela fundação Pierre Verger para o propósito dessa pesquisa. Em julho de 2018, passei uma semana no acervo do fotógrafo, encontrei 33 fotografias do Omo Ilê Agboulá e seu entorno (muitas sem identificação dos personagens retratados), obtive autorização para trabalhar com doze fotografias, nove delas apresentadas nesse artigo. E fotografias realizadas por Daniele, Emídia, Gustavo, Jaciara, Jonathan, Jamile, Layane e Lorrana, crianças moradoras do Alto da Boa Vista, com as quais eu saía todas as tardes para fotografar durante a viagem de campo no início deste ano. A identificação de todas as imagens foi realizada por adeptos do culto e moradores do entorno do Omo Ilê Agboulá. 
Festa das crianças, quando chegou a energia. (C) Arquivo Familiar

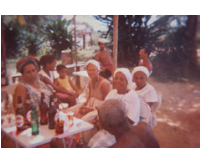

Ninha, caçula, Leonice, Silvéria. (C) Arquivo Familiar

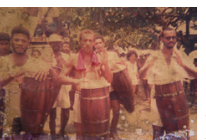

Djalma, Leco e Alagbá no ensaio do bloco de carnaval. (C) Arquivo Familiar

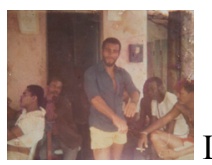

Luís, Djalma, Jaime e Nelsinho. (C) Arquivo Familiar

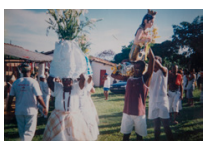

saída para entrega do presente das águas. (C) Arquivo Familiar

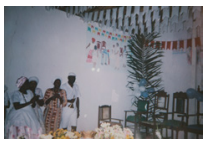

festa no barracão. (C) Arquivo Familiar

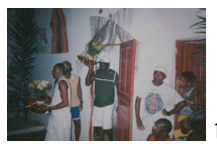

tio Cosme. (C) Arquivo Familiar
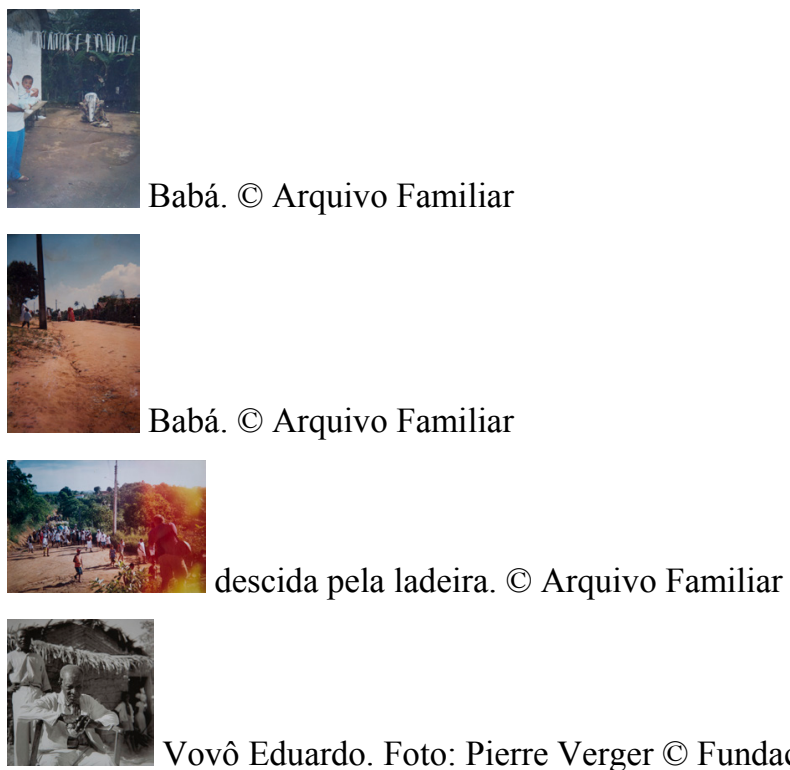

Vovô Eduardo. Foto: Pierre Verger (C) Fundação Pierre Verger

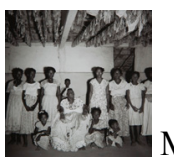

Mãe Senhora. Foto: Pierre Verger (C Fundação Pierre Verger

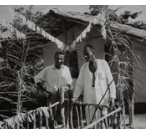

and . 
Rubelino e outros meninos. Foto: Pierre Verger (C) Fundação Pierre Verger

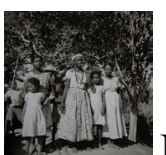

Não identificada. Foto: Pierre Verger (C) Fundação Pierre Verger

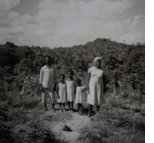

Silvéria. Foto: Pierre Verger (C) Fundação Pierre Verger

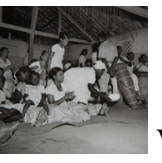

Vovó Julia entregando osé. Foto: Pierre Verger (C) Fundação Pierre Verger

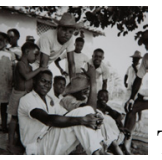

Tio Jaime. Foto: Pierre Verger (C) Fundação Pierre Verger

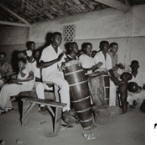

Tio Jaime. Foto: Pierre Verger (C) Fundação Pierre Verger
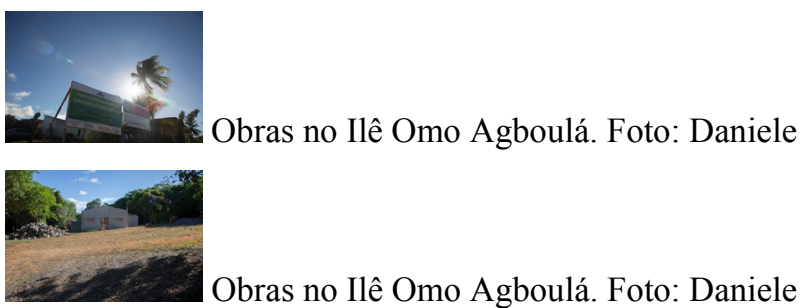

Obras no Ilê Omo Agboulá. Foto: Daniele

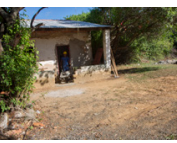

Obras no Ilê Omo Agboulá. Foto: Daniele

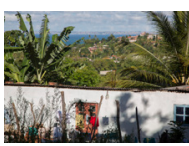

Alto da Bela Vista. Foto: Layane

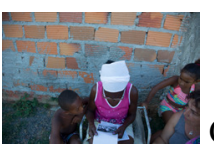

Crianças e Dona Toinha vendo fotografias de Pierre Verger. Foto: Gustavo

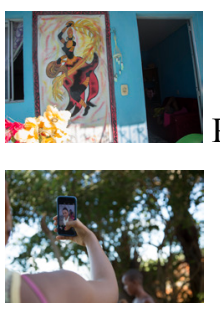

Pintura de Oyá na parede na entrada da casa de Bia. Foto: Jamile

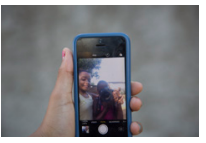

Selfie. Foto: Layane

Selfie. Foto: Lorrana e Layane

Iluminuras, Porto Alegre, v. 21, n. 53, p. 193-211, julho, 2020. 
Jonathan em frente ao muro na entrada do Agboulá. Foto: Gustavo

Animais pastando próximo a fonte do papo. Foto: Jonathan

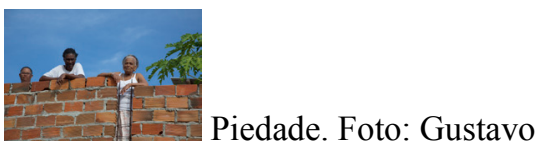

Casas no Alto da Bela Vista. Foto: Gustavo 


\section{REFERÊNCIAS}

BASTIDE, Roger. As religiões africanas no Brasil, (Segundo Volume). São Paulo: Editora da Universidade de São Paulo, 1971.

BRAGA, Júlio. Ancestralidade afro-brasileira: o culto de Babá Egum. Salvador: EDUFBA/Ianamá, 1995.

BENISTE, José. Orun Aiyé: O encontro de dois mundos. O sistema de relacionamento nagô-yorubá entre o céu e a Terra. Rio de Janeiro: Bertrand Brasil, 2010.

CAPUTO, Stela Guedes. Conhecimento e memória no culto de Egum: a confecção da casa- corpo da morte. Mneme Revista de Humanidades, 11(29), 2011, jan./jul., p. 665679. Disponível em: https://periodicos.ufrn.br/mneme/article/view/1017/996. Acesso em: 31 jan. 2020.

COUTO, Mia. Um rio chamdo tempo, uma casa chamada terra. São Paulo: Companhia das Letras, 2003.

GOLDMAN, Marcio. "A construção ritual da pessoa: a possessão no candomblé". Religião e Sociedade, 12(1):22-54, 1985.

GOLDMAN, Marcio. “A construção ritual da pessoa: a possessão no candomblé”.

"Formas do saber e modos do ser: observações sobre multiplicidade e ontologia no candomblé". Religião e Sociedade, 25(2):102-120, 2005.

GOLDMAN, Marcio. "O dom e a iniciação revisitados: o dado e o feito em religiões de matriz africana no Brasil”. Mana: estudos de antropologia social. Rio de Janeiro: Contra Capa, pp. 269-288, 2012.

ELBEIN DOS SANTOS, Juana. Os nàgô e a morte: pàde, àsèsè e o culto Égun na Bahia. Petrópolis: Vozes, 2012. 
FLAKSMAN, Clara. “De 'sangue' e 'de santo': o parentesco no candomblé”. Antropologias Afroindígenas: Contradiscursos e Contramestiçagens. $40^{\circ}$ Encontro Anual da ANPOCS, 2016.

FLAKSMAN, Clara. "Relações e narrativas: o enredo no candomblé da Bahia". Religião e Sociedade. Rio de Janeiro: UFRJ, 2016.

Disponível em: http://www.scielo.br/scielo.php?script=sci_arttext\&pid=S0100$85872016000100013 \& \operatorname{lng}=$ pt\&tlng=pt . Acesso em: 31 de janeiro de 2020.

JAGUN, Márcio de. Yorubá: vocabulário temático do candomblé. Rio de Janeiro: Litteris, 2017.

OXALÁ, Adilson de. Igbadu: a cabaça da existência. São Paulo: Pallas, 2006.

RABELO, Miriam C. M. Enredos, feituras e modos de cuidado: dimensões da vida e da convivência no candomblé. Salvador: EDUFBA, 2014.

SOUTY, Jérôme. Pierre Fatumbi Verger: do olhar livre ao conhecimento iniciático. São Paulo: Editora Terceiro Nome, 2011.

VELAME, Fábio M. O Opá ancestral: uma arquitetura de panos. In: II Seminário Arte e Cidade: Cultura, Memória e Contemporaneidade. Salvador: EDUFBA, 2008

VIANNA, Marisa. Baba Egum. Salvador: P555 Edições, 2008.

Recebido: $31 / 01 / 2020$

Aprovado: $15 / 07 / 2020$ 